\title{
ASSESSMENT OF MATURITY LEVEL: A STUDY OF QHSE CULTURE
}

\author{
A.G.S.Orlando ${ }^{\mathbf{1}^{*}}$; G.B.A.Lima ${ }^{\mathbf{1}}$; C.G.S.Abreu ${ }^{2}$
1 Universidade Federal Fluminense, 24210-240, Niterói-RJ, Brasil
2 Centro Federal de Educação Tecnológica Celso Suckow da Fonseca, 26041-271, Nova Iguaçu-RJ, Brasil
* angeloguido@id.uff.br
}

Submitted: 25/09/2018. Accepted: 29/12/2018

Published: 18/01/2019

\begin{abstract}
The aim of this paper is to present a model that quantifies the level of QHSE culture maturity in a segment of the oil and gas industry, with recommendations to increase the level of QHSE awareness. The theoretical reference is based on the understanding of the premises about safety culture and its aspects, while the methodological approach of this article is based on an exploratory study supported by a research with QHSE specialists in the segment. After analyzing the results and discussions, it was verified that the safety maturity level is high but needs some improvement points. Results showed that the presented evaluation method can be effective to evaluate the current state of the safety maturity, however, it is necessary to follow some basic prerequisites for its implementation.
\end{abstract}

KEYWORDS: safety culture, QHSE; management system, maturity.

\section{AVALIAÇÃO DE NÍVEL DE MATURIDADE: UM ESTUDO DA CULTURA DE QSMS}

\section{RESUMO}

O propósito deste artigo é explicitar um modelo de avaliação de maturidade acerca da cultura de QSMS e quantificar seu nível em um segmento da área da indústria de petróleo, apresentando recomendações para a elevação do nível de conscientização de QSMS. O referencial teórico fundamenta o entendimento das premissas sobre a cultura de segurança e seus aspectos, enquanto a abordagem metodológica deste artigo se alicerça em um estudo exploratório desenvolvido por uma pesquisa com especialistas de QSMS em atuação no segmento. Após a análise dos resultados e discussões, verificou-se que a maturidade de segurança é elevada com oportunidades de melhoria e que o método de avaliação apresentado pode ser eficaz para avaliar o estado atual da maturidade da segurança, contudo é necessário o cumprimento de alguns pré-requisitos básicos para sua implementação.

PALAVRAS-CHAVE: cultura de segurança, sistema de gestão; QSMS, maturidade. 


\section{INTRODUCTION}

Discussions on QHSE - Quality, Health, Safety and Environment - maturity levels are limited by difficulties in the identification of personal adhesion to the perceptions, beliefs and values contained in the basis of safety culture. QHSE management demands a wide, integrated vision of many knowledge domains, including aspects of risk management, information technology, business processes, human resources, personal and property safety, auditing and internal control, as well as legal and judicial requisites.

Maturity models are based on the fundamentals for guiding and measuring the implementation and the improvement of processes. QHSE maturity consists in the development of processes that become repetitive by their own nature, increasing their chances of assertiveness. However, there is no guarantee of success. The implementation of QHSE management methods and practices by companies is directly responsible for an increase in their maturity level. Therefore, it is necessary to conduct assessments of the companies' maturity regarding QHSE management in order to provide such companies with a way of identifying their own strengths and weaknesses, allowing for continuous improvement.

In the oil and gas segment, increasingly marked by complexity, uncertainty and ambiguity, organizations have been forced to innovate, develop efficient operational processes and provide reliable information in order not only to react, but also to predict technological innovation and the new demands and expectations of the markets. The organizational processes must be supported by information, which helps in the decision-making process and represents a source of organizational power, namely the power of swift problem solving and the power of easily learning from one's mistakes. Moreover, Germano and Araujo (2017) showed in their study that the standardization of industry processes increases organizational performance.

According to Gonçalves Filho, Andrade and Marinho (2011), nowadays, an integrated approach to matters of occupational safety, environment and culture represents a great challenge for improving workplaces and reducing the number of accidents. On the other hand, a production system of whichever nature is not deemed sustainable as long as the environment in which workers perform their activities is not safe nor healthy, but a cause of death, mutilation and disease.

Regarding considerations on safety, they pertain to key processes intrinsically aligned with organizational interests. Their main goal is guaranteeing operability in the face of possible incidents, avoiding financial losses, increasing productivity, providing higher quality to clients and advantages in comparison to competitors, as well as safeguarding the organization's reputation. However, in a real scenario, it is hard to predict all possible unplanned events. Many companies enforce inefficient safety measures in an attempt to increase protection. These measures are often expensive, and their results, subjective and questionable.

According to Gonçalves Filho, Andrade and Marinho (2011), cultural issues can, more often than not, present great barriers or obstacles to the changes required by the implementation of the Occupational Safety Management System. Therefore, knowing how mature is a company's culture is essential to the creation of a transformation plan whenever one is deemed necessary.

One of the many forms of process evaluation is through maturity models that allow for the identification of either a current stage or the evolution of a process in comparison to a previous measurement, pointing out where there is room for improvement. The maturity level allows for the assessment of any being, thing or system with the objective of determining their characteristics and performances, namely their weaknesses and strengths while operational. Given that safety is comprised of a set of procedures, the increase of its processes' maturity is not included in the items contained in existing normative models. 
Hence, this paper discusses QHSE culture maturity and processes maturity, allowing for the proposition of an assessment tool for QHSE processes in accordance with international norms and capable of adapting to the characteristics of drilling companies of the oil and gas segment.

The goal of this paper is to present and assess a system for the quantification of the QHSE culture maturity level in a segment of the oil industry's drilling sector, offering recommendations that might help in the increase of QHSE awareness levels. With that in mind, we propose the following question in order to guide our research towards the desired goals: What is the QHSE culture maturity level in the segment observed by this study and what recommendations can be made to increase said level?

The paper is organized in five parts. The first one presents an introduction of the theme, followed by an explanation on the materials and methods used, on the second part. The third part addresses the study's theoretical framework, and the fourth, its results and discussions. The last part of the paper presents our conclusions and due recommendations.

\section{MATERIALS AND METHODS}

Aiming to identify the current maturity stage of the QHSE culture, and following the model introduced by Hudson (2001), a questionnaire was created using Microsoft Excel and delivered via direct mail to the respondents. The scope of the research, its importance and all additional information were provided to the collaborators. In order to assess the QHSE culture maturity, a survey was organized as follows. The criteria were based on each step of the evolution of the maturity of a company's culture according to Hudson (2001).

The questions were created based on the triangulation of theoretical elements resulting from a bibliographical research conducted in Capes' journals database from May 13 ${ }^{\text {th }}, 2013$ to September $23^{\text {rd }}, 2013$; from the results of the survey conducted through the questionnaire sent out via e-mail from November $1^{\text {st }}, 2013$ to November $20^{\text {th }}, 2013$; and from the analysis conducted by the author based on his own professional experience as a QHSE manager in an international company of the oil and gas segment. The data collection tool was developed as a questionnaire of 30 questions, available in Annex 1, with answers presented on a scale, being one of them open-ended. For each of the first six clusters, seven questions were presented with the goal of collecting data for further analysis. The questionnaire was divided in seven clusters, whose topics and goals are presented in Table 1.

Table 1 - Separation in clusters of the survey's topics and goals

\begin{tabular}{|l|l|}
\hline Topic & Goals \\
\hline Demographic and Occupational Variables & $\begin{array}{l}\text { To identify the profile of the workers participating in the survey and their } \\
\text { relationship with their work/the company. }\end{array}$ \\
\hline Information on Occupational Safety & $\begin{array}{l}\text { To assess the level of reliance of the individuals on the organization to } \\
\text { report mistakes, accidents and incidents. }\end{array}$ \\
\hline Organizational Learning & $\begin{array}{l}\text { To assess how the organization treats its HSE data and whether or not they } \\
\text { continuously aim to improve processes. }\end{array}$ \\
\hline Communication & $\begin{array}{l}\text { To assess how and if the communications regarding HSE are understood } \\
\text { and effective, and whether or not there is an open channel between } \\
\text { employees and hierarchical superiors. }\end{array}$ \\
\hline Commitment & $\begin{array}{l}\text { To assess the resources (time, money, personnel) and the general support } \\
\text { allocated to HSE management, alongside the definition of responsibilities. }\end{array}$ \\
\hline Involvement & $\begin{array}{l}\text { To assess employee participation in matters of HSE, as well as how they } \\
\text { participate in the routines that present room for improvement in the area. }\end{array}$ \\
\hline Your Opinion & To assess the free participation of the staff's opinions in matters of safety. \\
\hline
\end{tabular}


Aiming to assess the reliability of the instrument, Cronbach's $\alpha$ was calculated. The resulting value was relatively low $-0.47-$, which points to a limitation of the research. Another possible limitation might derive from the small number of questions per cluster. This notion may be verified through the observation of the result of the sum of the variances, of the results obtained in the questionnaire, which are close to or higher than the value of the total variances of the respondents.

The internal consistency of the answers obtained via questionnaire has revealed that this measurement tool presented a low reliability in the places where the study was conducted. The value of calculation of Pearson's correlation coefficient presented only one value above 0.65 , which means that, in most cases, there is no linear correlation between the variables.

\section{LITERATURE REVIEW}

The idea of possessing and dominating knowledge is part of human nature. However, more than just possessing, nowadays, the goal is understanding the mechanisms involved in the transmission of knowledge and in the decision-making processes that separate experienced workers from new ones. With that in mind, it is necessary to permeate, at least slightly, the vast world of management with knowledge, with expertise, with the implicit and with the decision-making process (ARAÚJO et al., 2016).

Leadership, at this point, is directly connected to the organization's culture. It is the form of leadership adopted by the leader (businessman) that will set the tone and the direction towards which the company is moving. Though there is no way of dismissing the individual culture of the people working for the organizations, it is also not possible do disregard the need for the manager to adopt a leadership stance in order to direct the organization's progress (GONÇALVES et al., 2015).

Among the many different forms of process assessment, it is worth highlighting the assessment through maturity models that allows the identification of a current stage or of a process' evolution in comparison to a previous measurement, pointing out where there is room for improvement.

\subsection{Assessment of Safety Culture Maturity}

While analyzing an organization's culture, it is important to observe and determine whether or not the artifacts are easy to decipher and the values, capable of reflecting personnel behavior. With that in mind, we understand that an organization's identity has its inception in the values and assumptions of its founders. As the staff adapts to the environment, said assumptions become the foundation on which they build their own identity, their own cultural reality (JULIANI et al., 2016).

Maturity models involve a definition of maturity stages or levels that assess the completeness of the objects of analysis - usually, organizations or processes - through different sets of multidimensional criteria (WENDLER, 2012, BECKER et al., 2009).

Fleming (2001) used the concept of maturity to create a model for safety culture, aiming to help oil companies in the United Kingdom to assess the maturity level of their cultures and what actions would be necessary to improve it. Fleming's model (2001), with its five stages of safety culture maturity, is presented in Figure 1. 


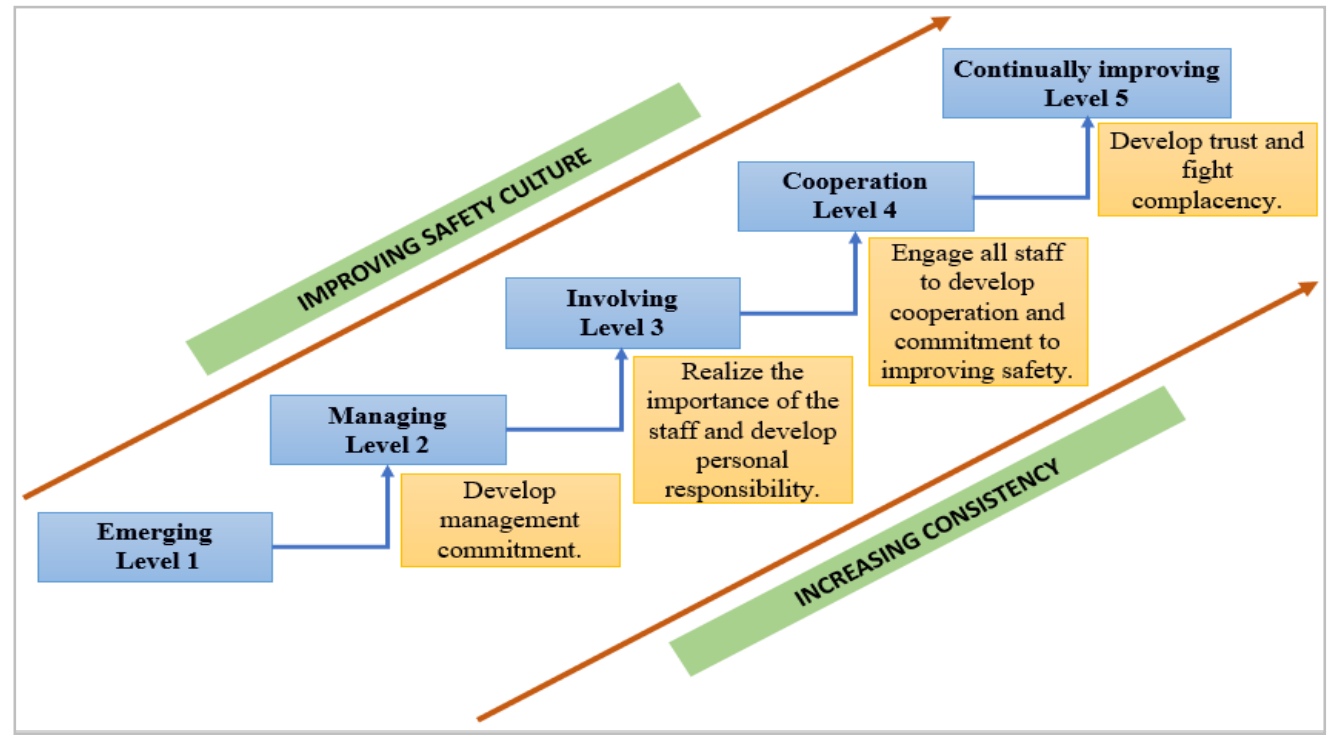

Figure 1 - Adapted from Fleming's safety culture maturity model Source: Adapted from Fleming (2001).

It is worth pointing out that Fleming (2001) warns that his model is only applicable to organizations that meet the following criteria: having an adequate occupational safety management system; most accidents not being caused by technical failures; complying to occupational safety laws and regulations; and using occupational safety as a way of preventing accidents.

Maturity models in safety culture are defined by Hudson (2007) as continuous, varying from organizations with an unsafe culture ("pathological" organizations) to those that manage safety proactively ("generative" organizations) and those that are in an intermediate development stage ("bureaucratic" organizations) (WESTRUM, 2004). Furthermore, Hudson (2001) states that there are five levels of progressive maturity, pictured in Figure 2.

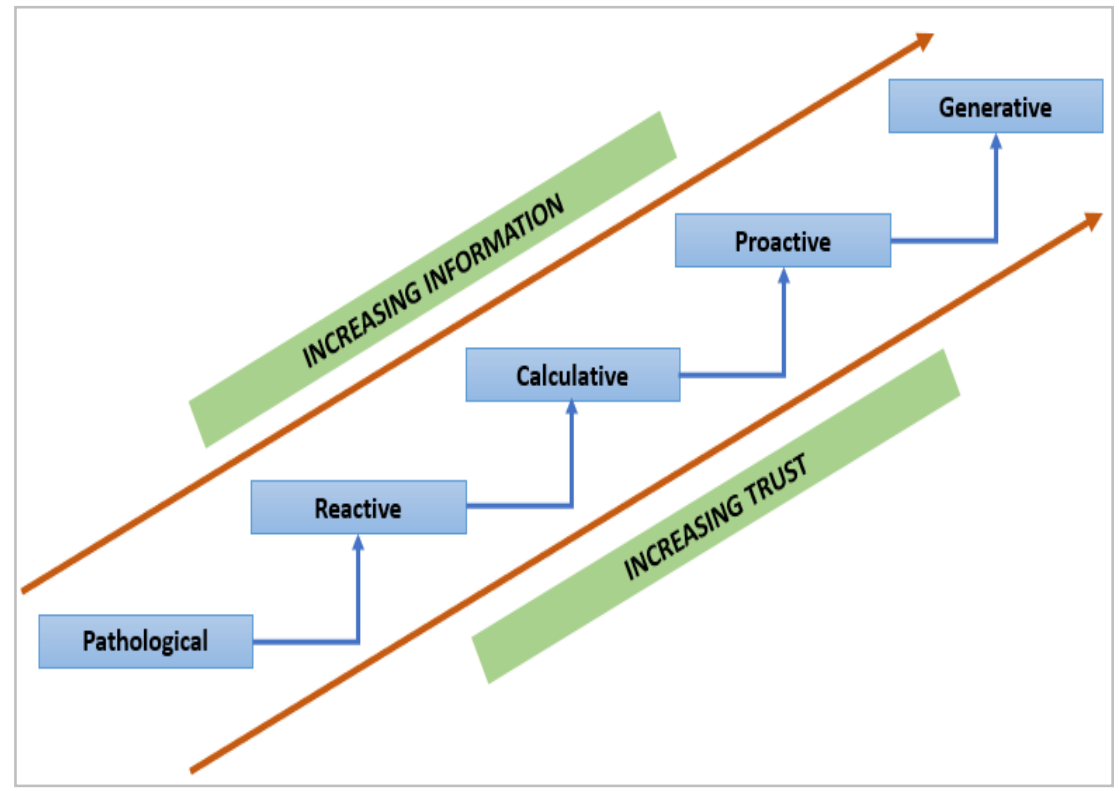

Figure 2 - Adapted from Hudson's safety culture maturity model Source: Adapted from Hudson (2001).

Culture maturity levels are described in Table 2: 
Table 2 - Culture maturity levels

\begin{tabular}{|l|l|}
\hline Level & Behavior \\
\hline Pathological & Aims, at most, to comply with legislation. \\
\hline Reactive & HSE actions are taken after accidents. \\
\hline Calculative & $\begin{array}{l}\text { The organization has a system to manage risks in the workplace, but still lacks a systemic vision of } \\
\text { HSE. }\end{array}$ \\
\hline Proactive & $\begin{array}{l}\text { Based on the organization's values, the leader conducts continuous improvements. The organization } \\
\text { aims to anticipate problems before they happen. }\end{array}$ \\
\hline Generative & $\begin{array}{l}\text { The organization possesses the information necessary to manage its HSE system and constantly } \\
\text { searches for better ways of controlling risks. }\end{array}$ \\
\hline
\end{tabular}

Source: Adapted from Hudson (2001).

According to Gonçalves Filho and Waterson (2018), maturity models are descriptive, meaning that they point out expected essential (key) attributes to characterize an organization on a particular level.

\subsection{Selection of maturity indicators}

In order to select the maturity indicators of a safety culture, according to Gonçalves Filho, Andrade and Marinho (2011), a revision of literature was conducted, and the five most frequently mentioned factors were chosen: information, organizational learning, involvement, communication and commitment.

The description of the five selected factors presented in the following table was done based on the authors presented below:

Table 3 - Safety culture maturity indicators

\begin{tabular}{|c|c|c|}
\hline Indicator & Definition & Authors \\
\hline Information & $\begin{array}{l}\text { Characterized by the individuals' trust in the organization in order to report } \\
\text { mistakes, accidents and incidents - an essential aspect of the construction of an } \\
\text { informed culture. It also includes the indicators generated by the organization in } \\
\text { order to monitor occupational safety performance. }\end{array}$ & $\begin{array}{ll}\text { REASON, } & 1997 ; \\
\text { HUDSON, } & 2001 ; \\
\text { AIEA, 2002. } & \end{array}$ \\
\hline $\begin{array}{l}\text { Operational } \\
\text { learning }\end{array}$ & $\begin{array}{l}\text { Characterized by the way in which the organization treats the received } \\
\text { information, how accidents and incidents are analyzed, whether or not actions } \\
\text { for improvement are proposed and implemented, whether or not the staff is } \\
\text { informed of said actions, and whether or not there is a continuous effort to } \\
\text { improve occupational safety processes. }\end{array}$ & $\begin{array}{l}\text { AIEA, } 2002 ; \\
\text { REASON, } 1997 .\end{array}$ \\
\hline Involvement & $\begin{array}{l}\text { Characterized by the staff's participation in safety matters, such as the analysis } \\
\text { of accidents and incidents pertaining to them; in the identification and the } \\
\text { analysis of workplace risks; in the proposal and the implementation of actions } \\
\text { for the improvement of occupational safety; in the creation and the revision of } \\
\text { procedures related to their work; in the planning of their work; and in safety } \\
\text { committees, meetings etc. }\end{array}$ & $\begin{array}{ll}\text { CHOUDHRY } & e t \\
\text { al., } & 2007 \text {; } \\
\text { GORDON et al., } \\
2007 .\end{array}$ \\
\hline Communication & $\begin{array}{l}\text { Characterized by how communications on themes pertaining to occupational } \\
\text { safety are done and if they are done in a convenient and timely manner; whether } \\
\text { or not there is an open communication channel between employees and } \\
\text { hierarchical superiors. It also pertains to whether or not said information reaches } \\
\text { the company's employees, whether or not it is understood by them, and whether } \\
\text { or not the organization monitors its effectiveness. }\end{array}$ & $\begin{array}{lr}\text { COOPER, } & 1998 ; \\
\text { GLENDON } & \& \\
\text { STANTON, } 2000 ; \\
\text { OLIVE } \text { et } \text { al., 2006; } \\
\text { MEARNS et al., } \\
\text { 2003; WESTRUM, } \\
\text { 2004. }\end{array}$ \\
\hline Commitment & $\begin{array}{l}\text { Characterized by the amount of resources (time, money, personnel) and the } \\
\text { general support allocated to occupational safety management, by the current }\end{array}$ & $\begin{array}{l}\text { DEJOY et al., } \\
\text { 2004; FLIN et al., }\end{array}$ \\
\hline
\end{tabular}




\begin{tabular}{|c|c|c|c|}
\hline & & $\begin{array}{l}\text { status of occupational safety in relation to production, by the existence of an } \\
\text { Occupational Safety Management System containing: the organizations vision } \\
\text { and goals; a definition of responsibilities; the organization's training policy and } \\
\text { qualifications; procedures; rewards; sanctions; and audits. True commitment } \\
\text { means more than written policies and mentions to the importance of } \\
\text { occupational safety in speeches. There needs to be a rapport between what is } \\
\text { said and what is done. }\end{array}$ & $\begin{array}{l}\text { 2000; AIEA, 2002; } \\
\text { OLIVE, et al., } \\
2006 .\end{array}$ \\
\hline
\end{tabular}

Source: Authors (2018).

According to Silbey (2009), the interpretation of culture as causal attitude is seen as measurable, comprehending the organizations' values, competencies, attitudes and behaviors regarding safety.

Vongvitayapirom et al. (2013) state that most critiques made by managers in relation to safety culture derive from the way's communications can be made visible and effective for the entire workforce. The goal needs to be increasing the awareness of all employees' regarding safety, which must be done through different communication methods with broad notions of technological improvement and cultural sensitivity.

For Hale (2006), maturity scales are the stages organizations go through from the pathological to the constructive level. However, it is hard to determine when it is possible to push an organization from one stage to the next. Therefore, longitudinal studies are necessary to increase the organizational learning curve, pushing companies to reach their maturity in a more swift and efficient manner.

Regarding safety culture assessment, Gonçalves Filho and Waterson (2018) argue that the preference for a maturity model as a form of evaluation over other methods (e.g.: focal groups, questionnaires, inquiries) must not be seen as mutually exclusive, i.e., either one model should be used or another. The authors also state that the flexibility provided by the maturity models might be considered strength in comparison to other methods of assessment of QHSE culture.

\section{RESULTS AND DISCUSSION}

While choosing the participants of the survey, we aimed to gather opinions from HSE professionals with theoretical knowledge and practical expertise on the drilling sector of the oil industry, both onshore and offshore.

The sample as a whole was comprised of 33 specialists, representing $47.14 \%$ of the population. The limited size of the sample does not represent a barrier for the research, since the group of respondents is comprised of experienced professionals in the aforementioned field.

- Universe: HSE Supervisors, Engineers, Technicians, Analysts and Assistants.

- Population: Target group of 70 professionals associated with the field of work analyzed by this study.

- Sample: a total of 33 respondents (47.14\% of the population).

The following graphs demonstrate that the respondents' profile is represented by $87 \%$ of the offshore professionals to whom the survey was sent. The profile identified was of workers with a high school education working in offshore operational activities that have been in the same company for over six years. The need to work overtime was brought up by $100 \%$ of the interviewees. 

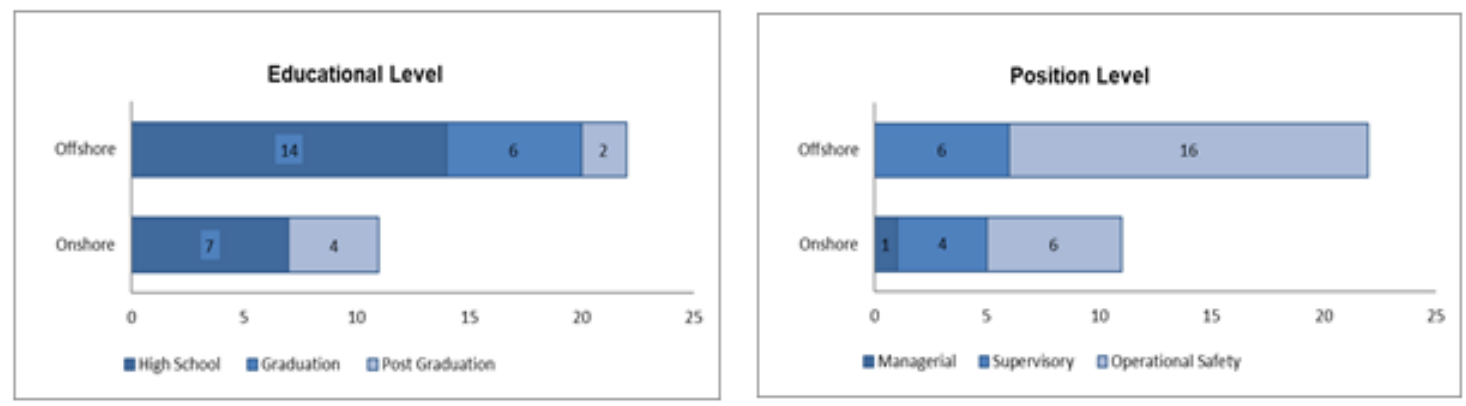

Figure 3 - Educational and Position Level Source: Authors (2018).

A third of the respondents have finished high school. Out of the ones that had a university education, half also finished post-graduation degree. In the onshore field, all workers with a university education also have some sort of advanced academic degree.

Job wise, the respondents are primarily workers of the offshore operational field, and a significant number of them occupy supervision positions.
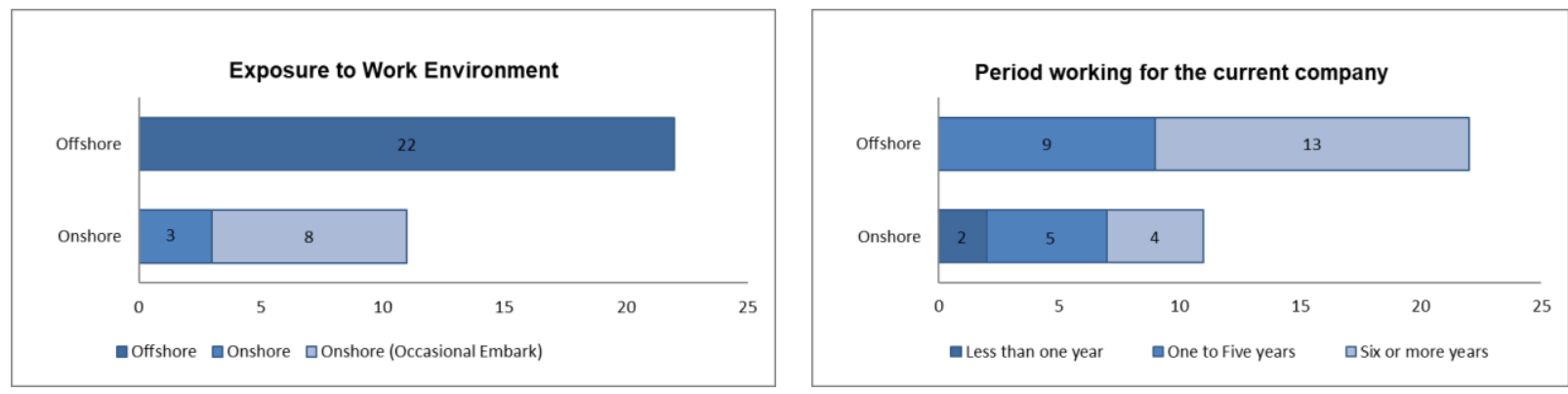

Figure 4 - Exposure to Work Environment and Period working for the current company Source: Authors (2018).

A third of the respondents work on-board. However, those that do not fit this description are intermittently and permanently subjected to the regime. In our sample, it is noticeable that more than half of the respondents have been working for their companies for over six years, while an insignificant minority has been on the same company for less than a year.

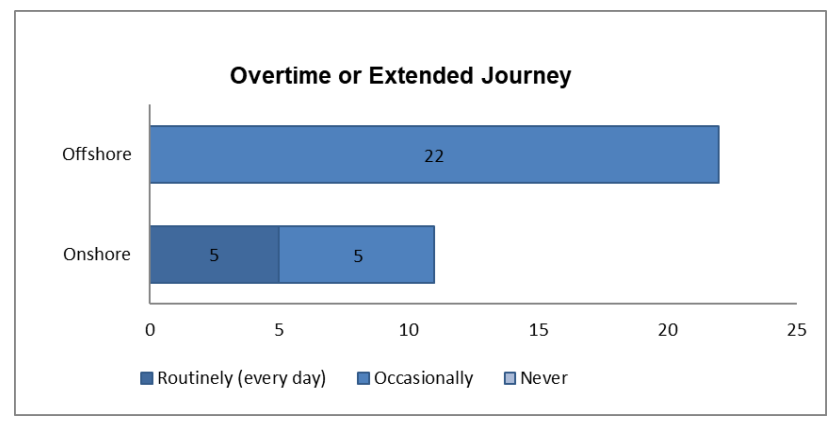

Figure 5 - Overtime or Extended Journey Source: Authors (2018).

All of the offshore respondents work overtime on an occasional basis, while $45 \%$ of the onshore respondents work overtime routinely. It is worth pointing out that the offshore work day is twelve hours long and that, legally, a break of, at least, eleven hours is recommended between work periods. 


\subsection{Examined topics}

An identification of the current level of the five topics, contemplated by questions with answers presented on a scale from one to five and a free question set for the survey, was conducted as follows, according to the model proposed by Hudson (2001):

Table 4 - "Information on occupational safety" is almost entirely in the proactive stage. Based on the answers given by the respondents, there is no significant divergence between the onshore and the offshore populations. The intermediate question, Question 3, was the one that presented the largest variation in the on-offshore spectrum. This, however, did not alter substantially the respondents' perception.

Table 4 - Information on occupational safety

\begin{tabular}{|c|c|c|c|c|c|c|c|c|c|c|c|c|c|c|}
\hline \multirow[b]{2}{*}{ QUESTIONS } & \multicolumn{2}{|c|}{1} & \multicolumn{2}{|c|}{2} & \multicolumn{2}{|c|}{3} & \multicolumn{3}{|c|}{4} & \multicolumn{2}{|l|}{5} & \multicolumn{2}{|l|}{ NS } & NA \\
\hline & zo & 岌 & z & $\frac{\mathrm{L}}{\mathrm{L}}$ & z & $\frac{11}{\mathbf{L}}$ & z & $\frac{1}{\mathbf{L}}$ & z & $\frac{14}{4}$ & z & 岌 & z & $\frac{11}{\frac{11}{0}}$ \\
\hline $\begin{array}{l}1 \text { - Abnormal incidents happening in the } \\
\text { company, regardless of severity or of whether } \\
\text { or not they result in accidents, are not } \\
\text { reported by the staff. }\end{array}$ & 4 & 10 & 2 & 6 & & 2 & 4 & 4 & 1 & & & & & \\
\hline $\begin{array}{l}2 \text { - Only abnormal incidents resulting in } \\
\text { severe accidents are reported by the staff. }\end{array}$ & 6 & 6 & 2 & 11 & & 3 & 3 & 1 & & 1 & & & & \\
\hline $\begin{array}{l}3 \text { - Only a small part of the employees is } \\
\text { comfortable (trust the company) with reporting } \\
\text { abnormal incidents that happen in the } \\
\text { company. }\end{array}$ & 2 & 5 & 2 & 5 & 5 & 1 & 2 & 3 & & 8 & & & & \\
\hline $\begin{array}{l}4 \text { - Most abnormal incidents that happen in } \\
\text { the company, regardless of severity and of } \\
\text { whether or not they result in accidents, are } \\
\text { reported by the staff. }\end{array}$ & & 1 & 2 & 1 & 1 & 1 & 4 & 16 & 4 & 3 & & & & \\
\hline $\begin{array}{l}5 \text { - All employees are comfortable (trust in the } \\
\text { company) with reporting abnormal incidents } \\
\text { that happen in the company. }\end{array}$ & 1 & 4 & 1 & 2 & 7 & 6 & 2 & 7 & & 3 & & & & \\
\hline
\end{tabular}

\begin{tabular}{|l|l|}
\hline Highest concentration of answers from onshore respondents. \\
\hline Highest concentration of answers from offshore respondents. \\
\hline
\end{tabular}

Source: Authors (2018).

Table 5 - "Organizational learning" is almost entirely in the proactive stage. Based on the answers given by the respondents, there is no significant divergence between the onshore and the offshore populations. Question 2 was the one that presented a wider variation in the on-offshore spectrum. This, however, did not substantially alter the respondents' perception.

Table 5 - Organizational Learning

\section{Item 3 - ORGANIZATIONAL LEARNING}

\begin{tabular}{|c|c|c|c|c|c|c|c|c|c|c|c|c|c|c|}
\hline \multicolumn{15}{|c|}{ Item 3 - ORGANIZATIONAL LEARNING } \\
\hline & \multicolumn{2}{|c|}{1} & \multicolumn{2}{|c|}{2} & \multicolumn{2}{|c|}{3} & \multicolumn{2}{|c|}{4} & \multicolumn{2}{|c|}{5} & \multicolumn{2}{|c|}{ NS } & \multicolumn{2}{|c|}{ NA } \\
\hline & z & $\frac{\mathrm{u}}{\mathrm{L}}$ & z & $\frac{\mathrm{L}}{\mathrm{L}}$ & z & 능 & z & $\frac{\mathrm{L}}{\mathrm{L}}$ & zo & $\frac{\mathrm{L}}{\mathbf{1}}$ & z & $\frac{\mathrm{L}}{\mathrm{L}}$ & $z$ & $\frac{\mathrm{L}}{\mathrm{L}}$ \\
\hline $\begin{array}{l}1 \text { - The company's assessment of abnormal } \\
\text { incidents is restrained to the identification of } \\
\text { culprits. }\end{array}$ & 6 & 14 & 3 & 3 & 2 & 5 & & & & & & & & \\
\hline
\end{tabular}


2 - The company's assessment of abnormal incidents is restrained to the identification of immediate causes.

3 - The company strives to improve occupational safety only in sectors that are more accident prone.

4 - The company assesses most abnormal incidents.

5 - The company assesses all abnormal incidents, regardless of severity and of whether or not they result in accidents.

\begin{tabular}{||l|l||l|l||l|l||l|l||l|l||l|l||l|l|}
\hline 3 & 4 & 5 & 4 & & 5 & 3 & 2 & & 7 & & & & \\
\hline \hline 4 & 10 & 2 & 7 & 5 & 4 & & 1 & & & & & & \\
\hline \hline & & & 3 & 3 & 4 & 4 & 7 & 4 & 8 & & & & \\
\hline \hline & 4 & 2 & 4 & 2 & 1 & 4 & 5 & 2 & 8 & & & & \\
\hline
\end{tabular}

Source: Authors (2018).

Table 6 - "Communication" is on the constructive stage, with some traces of the proactive stage. There is no divergence between the onshore and the offshore populations.

Table 6 - Communication

\section{Item 4 - COMMUNICATION}

\begin{tabular}{|c|c|c|c|c|c|c|c|c|c|c|c|c|c|c|}
\hline \multicolumn{15}{|c|}{ Item 4 - COMMUNICATION } \\
\hline & \multicolumn{2}{|c|}{1} & \multicolumn{2}{|c|}{2} & \multicolumn{2}{|c|}{3} & \multicolumn{2}{|c|}{4} & \multicolumn{2}{|c|}{5} & \multicolumn{2}{|c|}{ NS } & \multicolumn{2}{|c|}{ NA } \\
\hline & z & एᄂ. & 2 & $\frac{11}{0}$ & z & $\frac{11}{0}$ & z & $\frac{11}{0}$ & z & $\frac{11}{0}$ & z & $\frac{11}{6}$ & z & $\frac{14}{\mathrm{~L}}$ \\
\hline $\begin{array}{l}1 \text { - The communications on occupational safety } \\
\text { made by the company do not reach the staff. }\end{array}$ & 4 & 17 & 7 & 5 & & & & & & & & & & \\
\hline $\begin{array}{l}2 \text { - Only when a severe accident takes place does } \\
\text { the company open a communication channel on } \\
\text { occupational safety with the staff. }\end{array}$ & 5 & 12 & 2 & 5 & 2 & 2 & & 2 & 2 & 1 & & & & \\
\hline $\begin{array}{l}3 \text { - The communications on occupational safety } \\
\text { made by the company reach a small part of the staff. }\end{array}$ & 3 & 13 & 4 & 2 & & & 2 & 5 & 2 & 2 & & & & \\
\hline $\begin{array}{l}4 \text { - The news pertaining to occupational safety made } \\
\text { by the company are diverse and involve the use of } \\
\text { Personal Protective Equipment (PPE), lectures on } \\
\text { safety, accidents indicators, results of analysis of } \\
\text { abnormal incidents, health protection, improvements } \\
\text { on occupational safety etc. }\end{array}$ & & & & & 2 & 2 & 4 & 5 & 5 & 15 & & & & \\
\hline $\begin{array}{l}5 \text { - The communications on occupational safety } \\
\text { made by the company reach all of the staff. }\end{array}$ & 1 & & & & 4 & & 2 & 7 & 4 & 15 & & & & \\
\hline
\end{tabular}

Source: Authors (2018).

Table 7 - "Commitment" is on the proactive stage, with clear traces of the constructive stage. Question 5 was the item with the largest variation in the on-offshore spectrum. This, however, did not substantially alter the respondents' perception, and the onshore population sees an evolution in the maturity level.

Table 7 - Commitment

\begin{tabular}{|c|c|c|c|c|c|c|c|c|c|c|c|c|c|c|}
\hline \multicolumn{15}{|c|}{ Item 5 - COMMITMENT } \\
\hline & \multicolumn{2}{|c|}{1} & \multicolumn{2}{|c|}{2} & \multicolumn{2}{|c|}{3} & \multicolumn{2}{|c|}{4} & \multicolumn{2}{|c|}{5} & \multicolumn{2}{|c|}{ NS } & \multicolumn{2}{|c|}{ NA } \\
\hline & ž & $\frac{11}{0}$ & ž & $\frac{11}{0}$ & z & $\frac{11}{0}$ & z & $\frac{11}{0}$ & z & $\frac{\mathrm{L}}{\mathrm{L}}$ & z & $\frac{\mathrm{L}}{\mathrm{L}}$ & z & $\frac{11}{0}$ \\
\hline $\begin{array}{l}1 \text { - The company hires subcontractors not } \\
\text { concerned with occupational safety. }\end{array}$ & 5 & 9 & 4 & 7 & 2 & 2 & & 2 & & 1 & & 1 & & \\
\hline $\begin{array}{l}2 \text { - Occupational safety is only a priority for the } \\
\text { company in case of severe accidents. }\end{array}$ & 5 & 13 & 4 & 4 & 2 & 4 & & & & & & 1 & & \\
\hline
\end{tabular}


3 - The occupational safety procedures currently enforced by the company are aimed only at sectors that are accident prone.

4 - The company's occupational safety planning isn't integrated with the planning of other sectors of the company (e.g.: the production sector).

5 - The company does not need an occupational safety support team because the responsibility for the area is shared by the entire company.

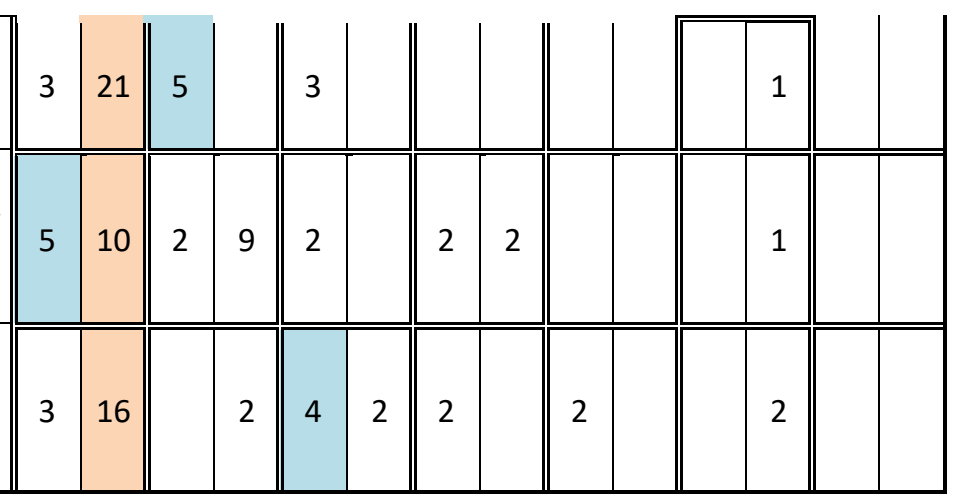

Source: Authors (2018).

Note: It is worth considering that item 5 might create a sentiment of class protection, since it's directly related to the respondents' employability. Item 6 - "Involvement" is on the calculative stage, in dissonance with the other items, that have been classified as proactive or constructive. Question 4 was the one that presented the largest variation in the on-offshore spectrum. This, however, did not substantially alter the respondents' perception.

Table 8 - Involvement

\begin{tabular}{|c|c|c|c|c|c|c|c|c|c|c|c|c|c|c|}
\hline \multicolumn{15}{|c|}{ Item 6 - INVOLVEMENT } \\
\hline & \multicolumn{2}{|c|}{1} & \multicolumn{2}{|c|}{2} & \multicolumn{2}{|c|}{3} & \multicolumn{2}{|c|}{4} & \multicolumn{2}{|c|}{5} & \multicolumn{2}{|c|}{ NS } & \multicolumn{2}{|c|}{ NA } \\
\hline & z & $\frac{11}{0}$ & z & $\frac{\mathrm{L}}{\mathrm{L}}$ & z & $\frac{11}{0}$ & z & $\frac{\mathrm{L}}{\mathrm{L}}$ & z & $\frac{11}{0}$ & z & $\frac{\mathrm{L}}{\mathrm{L}}$ & z & $\frac{\mathrm{L}}{\mathrm{L}}$ \\
\hline $\begin{array}{l}1 \text { - The staff does not participate in matters of } \\
\text { occupational safety in the company. }\end{array}$ & 2 & 10 & 5 & 7 & 4 & 4 & & & & 1 & & & & \\
\hline $\begin{array}{l}2 \text { - The staff is only interested in participating in the } \\
\text { Internal Committee on Accident Prevention (CIPA) } \\
\text { because of stability. }\end{array}$ & 2 & & & 1 & 5 & 2 & 2 & 10 & 2 & 9 & & & & \\
\hline $\begin{array}{l}3 \text { - A small fraction of the staff is interested in } \\
\text { participating in matters of occupational safety in the } \\
\text { company. }\end{array}$ & & 2 & 2 & 7 & 7 & 7 & & 5 & 2 & 1 & & & & \\
\hline $\begin{array}{l}4 \text { - Most employees participating in the Internal } \\
\text { Committee on Accident Prevention (CIPA) are } \\
\text { involved in matters of occupational safety in the } \\
\text { company. }\end{array}$ & & 4 & 2 & 12 & 4 & 5 & 5 & 1 & & & & & & \\
\hline $\begin{array}{l}5 \text { - All employees are interested in participating in } \\
\text { matters of occupational safety in the company. }\end{array}$ & 2 & 7 & 5 & 4 & 2 & 8 & 2 & 3 & & & & & & \\
\hline
\end{tabular}

Source: Created by the authors (2018).

The seventh and last item of the questionnaire, 7 - "Your Opinion", corroborated the global analysis of the survey's result. Though some were deemed to be on the proactive stage, the answers show that there is still room for improvement in order to achieve the constructive stage, especially regarding Item 6 - "Involvement", for a certain dissatisfaction with leadership figures and their examples has been observed. As an example, we quote the opinion of one of the onshore respondents: "There has to be maturity in growth". This statement demonstrates their dissatisfaction with the company's current organizational climate.

Likewise, in the responses given by the offshore sample, other matters were brought up. The most relevant among them are:

- "Supervisors do not follow procedure and are only concerned with results"; 
- "Great safety system with foreigners (line of supervision), this being a matter that deserves higher awareness";

- "The company has a good safety culture, with good campaigns, and the human factor is a crucial point. It is necessary to motivate people through leadership, for instance";

- "Production is prioritized instead of safety, especially by the supervisors; some deserved to be punished";

- "A strong and evolving safety culture, with an improvement in the commitment with safety when under operational pressure".

The opinions quoted are marked by the existence of room for improvement in the general behavior of the line of supervisors that, in many cases, prioritize operational continuity instead of safety. Leadership figures responsible for elevating the QHSE culture maturity level generate, through their behavior, a complete opposite effect, setting inappropriate examples.

Similarly, to occupational safety, matters of organizational learning also reached a proactive level of maturity. The analysis indicated a level of maturity, in most cases where incidents were assessed, that aims towards a continuous improvement, and not just the identification of culprits.

With a level of maturity between the constructive and the proactive stages, communication presents only a slight divergence of opinions between the onshore and the offshore respondents, with the latter considering the item to be in a more evolved stage. Questions about this topic aimed to measure how far QHSE communication can reach and in what scenarios. In effect, it is possible to say that QHSE communication reaches the majority of workers, if not all of them.

We can also state that Item 5 - "Commitment of critical analysis" is on the proactive stage, with clear traces of a constructive level. There is a slight divergence of opinion between the onshore and the offshore populations, with the latter seeing an evolution in the maturity level. Note: it is worth taking into consideration that the question/statement "The company does not need an occupational safety support team because the responsibility for the area is spread through the entire company" can elicit a sentiment of class protection among HSE professionals, since it is directly related to their employability.

The item "Involvement" aimed to measure the level of participation of the workforce. In this sense, some questions are bound to generate controversy on the offshore business, like the ones pertaining to the Internal Committee on Accident Prevention (CIPA). This was brought up in order to ratify doubts surrounding the employees that participate in the committee and what it is for. Questions not pertaining directly to the CIPA also don't demonstrate an optimistic view of the involvement, for, during the assessments, it was evident that not everyone is interested in matters of QHSE.

Judging from Item 7 of the survey and the results obtained in the other items, the result of this research can be classified as being in the proactive stage. The other items show that there is still room for improvement, especially in matters of involvement, for a great deal of dissatisfaction with leadership figures has been identified. This item was created as an open-ended question so that the workers could express their opinions.

To summarize the final result, we present a visual representation of the point each cluster occupies in the evolutionary scale of safety culture maturity: 


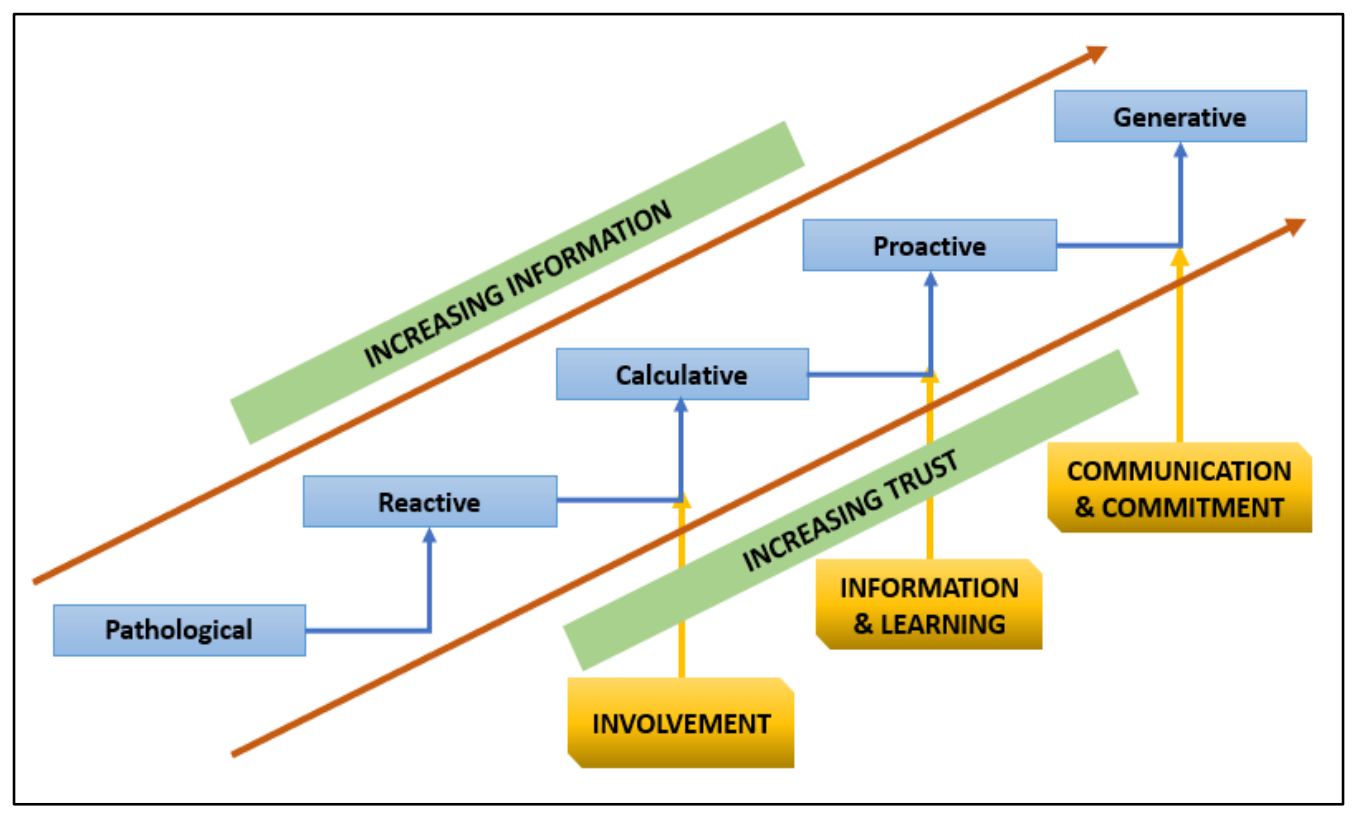

Figure 6 - Safety culture maturity model proposed by Hudson Source: Adapted from Hudson (2001).

The arguments presented herein grant validity to this research, for it is about a set of elements for establishing an evaluation resource with minimal and simple standards for assessing the maturity level of an organization or segment.

Clearly, one must not hold the false belief that the methodology is applicable by any professional. It is necessary to know the theory and to understand the effects of applying the tool as well as the representation of the target group's sample. A frequent reassessment is also deemed necessary, for this is a topic of continuous evolution, just like a program. The level of maturity of an organization's QHSE culture is not measured only for the sake of observation. The implementation of certain actions is to be expected, as well as the assessment of their efficacy once they have been put in place.

Based on the papers read during the exploratory process and on the authors' own experience, we present several recommendations for the elevation of the level of elements forming a company's safety culture maturity model:

1. Mission, Vision and Policy: The company must state them via their highest leadership figures.

2. Code of ethical conduct: The company must establish and divulge it.

3. Hiring process: The company must assess if the concern with QHSE is a value held by the candidate.

4. Training process: Add QHSE values to all training processes.

5. QHSE induction: Must be applied to all new workers, and periodically to old ones.

6. QHSE guidance: All workers must first go through guidance.

7. Personal and Collective Protective Equipment: Its usage must be seen as a value, not a demand.

8. Monitoring and identification of workers on probation period: New workers must be monitored until they are apt. 
9. Supervisors' role: The position level is responsible for instructing workers on what is expected of them regarding QHSE and monitor its execution.

10. Meetings: Must be held, and open questions must be encouraged.

11. Risk analysis: All workers must be able to assess and identify risks in order to safeguard their own integrity.

12. Emergency plans: All workers must be aware of their unity's emergency plan.

13. Lessons learned: Must be shared, and preventive actions, implemented.

14. Campaigns: The company must hold periodical QHSE awareness campaigns.

15. Communication: Open communication between different levels of the organization must be encouraged, with a focus on mutual trust instead of punishments.

16. Change management: All processes under work that require unplanned changes must be interrupted and undergo new planning.

17. Performance indicators: The company must not use operational performance indicators that might affect the workers' safety level.

18. Conformity assessment and application of requirements: The company must monitor new requirements (be they internal, legal or contractual) or changes made to them.

19. Safety Operational Stand Down: Must be conducted with the participation of management in order to ratify safety practices, breaking the paradigm of operational continuity.

20. Audits and Inspections: To create and apply regular devices to assess the efficacy of processes, and to conduct audits in order to keep up with requirements.

22. Just Culture Model: To implement Hudson's (2008) Just Culture Model in a way that its workings, as well as the causes and consequences of its implementation, are understood by all.

23. Subcontracted companies and employees: Must follow the same criteria above.

\section{CONCLUSION}

Based on this study, it is unlikely that the elements of the QHSE culture maturity model can map precisely the factors measured previously by the companies through researches, climate or QHSE audits, for there is a considerable variation in the QHSE culture elements proposed by an organization. Some researchers argue that QHSE culture is comprised of the safety-oriented behavior of an organization's collaborators, while others state that it is way broader, incorporating organizational systems, behaviors, values, beliefs and symbols. The elements used in the QHSE culture maturity model, present in most popular theoretical and measurement models, are: the commitment to management and visibility, communication, productivity versus safety, learning organization, resources for safety, participation, shared perceptions of safety, trust, training, work relations, and workers satisfaction.

The evaluation method presented might be useful to assess the current safety maturity state in order, to help in the identification of risks and in management, and to support the improvement of internal controls and processes. The goal of this paper is to present and evaluate a quantification system for the QHSE culture maturity level in a segment of the drilling sector of the oil industry, presenting recommendations that might be enforced in order to improve the level of QHSE 
awareness. In this sense, the paper points out that, in order to quantify a safety culture's maturity, some basic prerequisites must be met:

- The implementation of a model to be followed, with well-defined elements, and the proposal of a methodology for quantifying them.

- The conduction of audits with quantifiable results of the organizations ability to adhere to a prerequisite, for instance, in order to conduct a cross-sectional analysis between the model's elements.

Among the evaluation points was the workers' predisposition to report anomalies. This showed a result lower than expected. In a proactive level, one would expect abnormal incidents to be reported, regardless of severity.

\section{REFERENCES}

AGÊNCIA INTERNACIONAL DE ENERGIA ATÔMICA. Self-assessment of safety culture in nuclear installations: highlights and good practices. Viena, 2002b. 29 p. Disponível em: http://www.china-nea.cn/files/2014-4/43\%20selfassessment\%20of\%20safety\%20culture\%20in\%20nuclear\%20installations.pdf $>$. Accessed on March 20th, 2018.

ARAÚJO, G. F. S.; FIGUEIREDO, V. G. C.; JÚNIOR, H. J. R.; FIGUEIREDO, M. K. A percepção dos trabalhadores experientes no processo de tomada de decisão. GEPROS. Gestão da Produção, Operações e Sistemas, Bauru, v.11, n.1, p. 127-143, 2016.

BECKER J.; KNACKSTEDT, R.; PÖPPELBU, J. Developing maturity models for IT management - a procedure model and its application. Business \& Information Systems Engineering, v.3, p. 213-222, 2009.

CHOUDHRY, R. M.; FAG, D.; MOHAMED, S. The nature of safety culture: a survey of the state-of-the-art. Safety Science, n. 45, p. 903-1012, 2007.

COOPER, D. Improving safety culture: a practical guide. Londres: Wiley, 1998. 318 p. Disponível em: <http://www.scielo.br/scielo.php?script=sci_nlinks\&ref=000147\&pid=S0104-530X201100010001500005\&lng=pt $>$.

Accessed on March 20th, 2018.

DEJOY, D. M.; SCHAFFER, B. S.; WILSON, M. G.; VANDENBERG, R. J.; BUTTS, M. M. Creating safer workplaces: assessing the determinants and role of safety climate. Journal of Safety Research, n. 35, p. 81-90, 2004.

FLEMING, M. Safety culture maturity model. Health and Safety Executive Colegate, Norwich, 2001.

FLIN, R.; MEARNS, K.; O'CONNOR, P.; BRYDEN, R. Measuring climate: identifying the common features. Safety Science, n. 34, p. 177-192, 2000.

GERMANO, A. L.; ARAUJO, F. O. Desenvolvimento e implantação de propostas para a formalização de processos de manufatura de uma empresa fabricante de dutos industriais em Nova Iguaçu/RJ. Revista Produção e Desenvolvimento, v. 3, n. 3, p. 55-73, 2017.

GLENDON, A. I.; STANTON, N. A. Perspectives on safety culture. Safety Science, n. 34, p. 193-214, 2000.

GONÇALVES FILHO, A. P.; ANDRADE, J. C. S.; MARINHO, M. M. O. Cultura e gestão da segurança no trabalho: uma proposta de modelo. Gestão e Produção, São Carlos, v. 18, n.1, p. 205-220, 2011.

GONÇALVES FILHO, A. P.; WATERSON, P. Maturity models and safety culture: A critical review. Safety Science 105, p. 192-211, 2018.

GONÇALVES, A.; TREVISOL, N. P.; LOPES, M. C.; SOETHE, J. S. A relação entre liderança e cultura organizacional: um estudo realizado em uma IES. GEPROS. Gestão da Produção, Operações e Sistemas, Bauru, v.10, n.2, p.85-100, abr-jun/2015.

GORDON, R.; KIRWAN, B.; PERRIN, E. Measuring safety culture in a research and development centre: A comparison of two methods in the Air Traffic Management domain. Safety Science, n. 45, p. 669-695, 2007.

HALE, A. Method in Your Madness: System in Your Safety. Rede, Delft University of Technology, 15th September (2006).

HUDSON, P. Aviation safety culture. Safeskies, p. 1-23, 2001. 
HUDSON, P. Meeting expectations: A new model for a Just and Fair Culture, 2008. Disponível em: <https://www.onepetro.org/conference-paper/SPE-111977-MS>. Accessed on March 20th, 2016.

HUDSON, P. Implementing a safety culture in a major multi-national. Safety Science, v.45, p.697-722, 2007.

JUliANI, M. P.; AMARANTE, M. V.; BESSI, V. G.; COSTA, C. Cultura organizacional e sucessão em um laboratório de análises clínicas. GEPROS. Gestão da Produção, Operações e Sistemas, Bauru, v.11, n.2, p. 155-171, abr-jun/2016.

MEARNS, K.; WHITAKER, S. M.; FLIN, R. Safety climate, safety management practice and safety performance in offshore environments. Safety Science, n. 41, p. 641-680, 2003.

OLIVE, C.; O'CONNOR, T. M.; MANNAN, M. S. Relationship of safety culture and process safety. Journal of Hazardous of Materials, n. 130, p. 133-140, 2006.

REASON, J. Managing the risks of organizational accidents. Inglaterra: Ashgate Publishing Limited, 1997.252 p.

VONGVITAYAPIROM, B., SACHAKAMOL, P., KROPSU-VEHKAPERA, H. AND KESS, P. Lessons learned from applying safety culture maturity model in Thailand. International Journal of Synergy and Research, v. 2, n. 1, p. 5-21, 2013.

WENDLER, R. The maturity of maturity model research: a systematic mapping study. Information and Software Technology, v. 54, p. 1317-1339, 2012.

WESTRUM, R. A typology of organizational cultures. Quality and Safety in Health Care, v.13, p.22-27, 2004.

All authors stated that they had: a) actively participated in the discussion of the results; and b) Review and approval of the final version of the paper.

This work is licensed under a Creative Commons Attribution 4.0 International License. CC-BY 